\title{
ROOT SYSTEM DISTRIBUTION OF SUGARCANE IRRIGATED WITH DOMESTIC SEWAGE EFFLUENT APLICATION BY SUBSURFACE DRIP SYSTEM
}

\author{
ALLAN C. M. DE SOUSA ${ }^{1}$, EDSON E. MATSURA ${ }^{2}$, MARCELO L. C. ELAIUY ${ }^{3}$, \\ LEONARDO N. S. DOS SANTOS ${ }^{4}$, CÉLIA R. MONTES ${ }^{5}$, REGINA C. DE M. PIRES ${ }^{6}$
}

\begin{abstract}
Irrigation with domestic sewage effluent (DSE) has been recommended by subsurface dripping, as it can obtain a high rate of irrigation efficiency and faster use of salts in comparison with other irrigation methods. The study aimed at evaluating the area, the length and the effective depth of the root system of sugarcane irrigated with DSE by subsurface drip system and with different irrigation rates at depths of $0.00-0.20,0.20-0.40,0.40-0.60$ and $0.60-0.80 \mathrm{~m}$. The experiment was carried out in the municipality of Piracicaba, in the state of São Paulo (SP), Brazil, in a sugarcane area irrigated with DSE in a completely randomized blocks set up in furrows, with three replications and four treatments, which are: one area without irrigation (AWI) and three irrigated areas meeting 50\% (T50\%), 100\% (T100\%) and 200\% (T200\%) of the crop's water need between each round of irrigation. T100\% and T200\% provided smaller areas and lengths of roots in the two deepest layers, as compared to AWI and T50\%, which stimulated the development of deeper roots due to the water stress. TWI, T100\% and T200\% presented $80 \%$ of the roots up to a depth of $0.40 \mathrm{~m}$ and $\mathrm{T} 50 \%$ treatment presented $76.43 \%$ of roots total.
\end{abstract}

KEYWORDS: Root; water reuse; subsurface drip.

\section{DISTRIBUIÇÃO DO SISTEMA RADICULAR DA CANA-DE-AÇÚCAR IRRIGADA COM EFLUENTE DE ESGOTO DOMÉSTICO POR GOTEJAMENTO SUBSUPERFICIAL}

RESUMO: A irrigação com efluente de esgoto doméstico (EED) tem sido recomendada para aplicação por gotejamento subsuperficial, podendo-se obter elevados índices de eficiência de irrigação e mais rápido aproveitamento dos sais em comparação com outros métodos de irrigação. O trabalho objetivou avaliar a área de raiz, o comprimento e a profundidade efetiva do sistema radicular da cana-de-açúcar irrigada com EED aplicado por gotejamento subsuperficial e com diferentes lâminas de irrigação, nas camadas de solo de 0,00-0,20; 0,20-0,40; 0,40-0,60 e 0,60-0,80 m. O experimento foi realizado em Piracicaba-SP, numa área de cana-de-açúcar irrigada com EED, em um delineamento de blocos casualizados dispostos no esquema de faixas, com três repetições e quatro tratamentos, sendo estes: uma área sem irrigação (TSI) e três áreas irrigadas, atendendo a 50\% (T50\%), 100\% (T100\%) e 200\% (T200\%) da necessidade hídrica da cultura entre cada turno de rega. O T100\% e o T200\% proporcionaram menores áreas e comprimento de raízes nas duas camadas mais profundas, quando comparados ao TSI e ao T50\%, que devido ao estresse hídrico, proporcionado à cultura, estimularam o desenvolvimento de raízes mais profundas. O TSI, T100\% e T200\% apresentaram $80 \%$ das raízes até $0,40 \mathrm{~m}$ e, nessa mesma profundidade, o tratamento T50\% apresentou 76,43\% do total de raízes.

PALAVRAS-CHAVE: Raiz; reúso de água; gotejamento enterrado.

\footnotetext{
${ }^{1}$ Engenheiro Agrônomo, Mestre e Doutorando em Engenharia Agrícola na área de Água e Solo, pela FEAGRI/UNICAMP.

${ }^{2}$ Prof.Dr. Faculdade de Engenharia Agrícola - Universidade Estadual de Campinas.

${ }^{3}$ Engenheiro Ambiental e Sanitarista.

${ }^{4}$ Engenheiro Agrônomo e Mestre em Produção Vegetal pelo CCA/UFES, Doutorando em Engenharia Agrícola pela FEAGRI/UNICAMP.

${ }^{5}$ Universidade de São Paulo, Centro de Energia Nuclear na Agricultura CENA-USP, NUPEGEL/USP, Piracicaba, São Paulo, crmlauar@usp.br.

${ }^{6}$ Engenheira Agrônoma e Pesquisadora Científica,Centro de Ecofisiologia e Biofísica do Instituto Agronômico de Campinas (IAC). Recebido pelo Conselho Editorial em: 31-7-2012

Aprovado pelo Conselho Editorial em: 8-1-2013
} 


\section{INTRODUCTION}

The use of sewage effluent in agricultural irrigation has been presented as a viable alternative for the disposal of wastewater, especially for its agronomic benefits, in which the water supply of vegetables and provision of essential nutrients for plant growth, appear as the main benefits the reuse (KALAVROUZIOTIS et al., 2009; FONSECA et al., 2007; SANDRI et al., 2009; DEON et al. 2010, SANTOS et al., 2010).

In Brazil there is not a legislation that regulates the use of sewage effluent (DSE) in agriculture for commercial purposes, which is used only for researches, in which the system of subsurface drip irrigation presents itself as the most recommended for application mainly by reducing the risk of contamination of vegetables and operators that use this technique. This system is characterized by its high efficiency in the application of water and nutrients, and the reduction of water losses by evaporation and percolation (BARROS et al., 2009; BARROS et al., 2010; RIBEIRO et al., 2010), once the water and nutrition supply is performed directly or near the root zone of plants.

Thus, knowledge of the architecture of the root system of any culture constitutes an important tool for the development of a good irrigation project, since the understanding of root distribution in the soil is basic to determine the required amount of water to be applied and define the most appropriate positioning of sensors to monitor soil moisture (COELHO et al., 2007; NEVES et al., 2008; RAMOS, et al., 2009; COELHO et al., 2010).

Furthermore, the development of the roots directly influences some plant characteristics such as, for example, tolerance to droughts, nutrient absorption, resistance to pests and germination potential. However, it is not the amount of roots that determines the behavior of these variables, but the architecture of the same distribution in the soil profile (VASCONCELOS \& GARCIA, 2005). According to COSTA et al. (2007), plants with uneven distribution of the root system are often more susceptible to reduced production, especially when the rainfall events are infrequent.

The cultivation of sugarcane, when irrigated, emits the faster root system, so that the upper layers, which are moister, have a larger volume of roots compared to rainfed farming systems which, in turn, promotes root growth in deeper layers. According to FARIAS et al. (2008) for irrigated and non-irrigated soils, on average, about $85 \%$ of the root system of sugarcane is located in the first $0.60 \mathrm{~m}$ deep.

However, in the case of localized irrigation, only the knowledge of the effective depth of the roots is inadequate to determine the areas of uptake of water and nutrients, since the dynamic distribution of water in the soil is multidimensional, different from the one-dimensional behavior provided by sprinkler irrigation (COELHO et al., 2005). Therefore, as much knowledge as possible regarding the horizontal and vertical distribution of root crops in the soil profile is needed.

This study aimed at evaluating the root effective area, length and depth of the SP-903414 sugarcane root system, irrigated with sewage effluent by subsurface drip irrigation at different irrigation depths and soil layers.

\section{MATERIAL AND METHODS}

The experiment was installed in 2006 in Piracicaba, state of São Paulo (SP), Brazil $\left(22^{\circ} 4^{\prime}\right.$ 24" S, $47^{\circ} 36^{\prime} 32^{\prime \prime}$ W), at Santa Helena Farm, in an area of sugarcane crop belonging to the COSAN group, located next to the Sewage Treatment Station (STS) of the neighborhood CECAP, managed by the Municipal Water and Wastewater Treatment - sad SEMAE. However, this study only presents data from June 2010, corresponding to the third ratoon crop of sugarcane and to the fourth year of the experiment.

According to KÖPPEN, the region climate is a humid subtropical one, type Cwa, with the warmest temperatures exceeding $22^{\circ} \mathrm{C}$ and during the coldest month they are below $18^{\circ} \mathrm{C}$. Annual 
rainfall in the region is $1,328 \mathrm{~mm}$ and the predominant soil type was classified as eutrophic Red Yellow Argisol, and its chemical and granulometric characteristics, prior to the experiment, in 2006, are shown in Table 1.

TABLE 1. Soil chemical and granulometric characterization before implementing the experiment in 2006 (DEON, 2010).

\begin{tabular}{|c|c|c|c|c|c|c|c|c|c|}
\hline \multirow{2}{*}{$\begin{array}{l}\text { Soil layers } \\
\text { (m) }\end{array}$} & M.O. & $\mathrm{pH}$ & $\mathrm{P}$ & $\mathrm{K}^{+}$ & $\mathrm{Ca}^{2+}$ & $\mathrm{Mg}^{2+}$ & $\mathrm{Na}^{+}$ & $\mathrm{Al}^{3+}$ & $\mathrm{Al}^{3+}+\mathrm{H}^{+}$ \\
\hline & $\mathrm{G} \mathrm{kg}^{-1}$ & - & $\mathrm{Mg} \mathrm{kg}^{-1}$ & \multicolumn{6}{|c|}{ 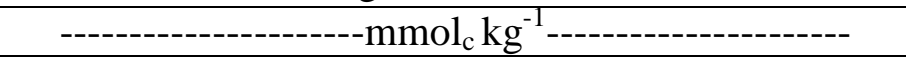 } \\
\hline $0.00-0.20$ & 25.00 & 6.07 & 8.57 & 1.90 & 31.87 & 17.12 & 0.31 & $<1$ & 21.87 \\
\hline $0.20-0.40$ & 22.20 & 5.60 & 6.37 & 0.75 & 22.50 & 11.25 & 0.37 & $<1$ & 24.50 \\
\hline $0.40-0.60$ & 17.75 & 5.30 & 4.02 & 0.45 & 19.25 & 8.25 & 0.40 & 1.5 & 25.00 \\
\hline \multirow[t]{2}{*}{$0.60-0.80$} & 17.00 & 4.95 & 4.00 & 0.37 & 14.75 & 7.25 & 0.42 & 2.0 & 25.50 \\
\hline & & \multicolumn{8}{|c|}{ Granulometry } \\
\hline \multirow{3}{*}{$\begin{array}{l}\text { Soil layers } \\
\text { (m) }\end{array}$} & \multirow{2}{*}{ Clay } & \multirow{2}{*}{ Silt } & \multicolumn{3}{|c|}{ Sand } & \multirow{2}{*}{\multicolumn{2}{|c|}{ WDC }} & \multirow{2}{*}{ FI } & \multirow{2}{*}{ DI } \\
\hline & & & & he & Coarse & & & & \\
\hline & \multicolumn{9}{|c|}{ 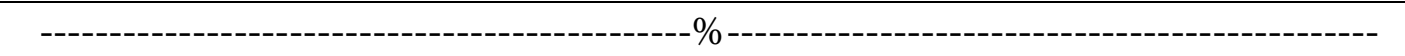 } \\
\hline $0.00-0.20$ & 45.23 & 24 & & 91 & 6.26 & & & 70.20 & 29.79 \\
\hline $0.20-0.40$ & 49.48 & 22 & & 63 & 5.90 & & & 84.38 & 15.79 \\
\hline $0.40-0.60$ & 53.85 & 18 & & 50 & 5.68 & & & 98.55 & 1.44 \\
\hline $0.60-0.80$ & 52.40 & 19 & & 75 & 5.48 & & & 98.33 & 0.89 \\
\hline
\end{tabular}

M.O. = Organic matter; WDC = Water-dispersible clay; FI = Flocculation index; DI= Dispersion index.

The experiment consisted of randomized blocks set up in furrows with 4 treatments and 3 replications, totaling 12 units, each divided into 4 subplots corresponding to soil layers of 0.00-

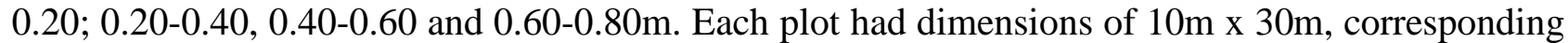
to an area of $300 \mathrm{~m}^{2}$, with six planting furrows spaced $1.4 \mathrm{~m}$ from each other, of which only the first one was not irrigated and, therefore, considered "blind line".

The treatments were based on irrigation with treated DSE, with depths of 50\% (T50\%), 100\% (T100\%) and 200\% (T200\%) of the crop water need based on the evapotranspiration between each irrigation round. Besides these treatments it was used an area without irrigation (TWI) as a control treatment.

The sugarcane species cultivated was the SP-903414, which is characterized by its upright position, high productivity, since it has little flowering and drying out. Trees were planted at $0.30 \mathrm{~m}$ deep and fertilization was carried out in accordance with the recommendation of the soil chemical analyzes (120kg ha- of $\mathrm{N}$, 30kg ha ${ }^{-1}$ of $\mathrm{P}_{2} \mathrm{O}_{5}$ and $120 \mathrm{~kg} \mathrm{ha}^{-1}$ of $\mathrm{K}_{2} \mathrm{O}$ ) following the recommendations of RAIJ et al. (1996).

The DSE was from the sewage treatment station (STS) of the CECAP neighborhood, which consists of Australian stabilization ponds, with one anaerobic receptive pond and two facultative ponds, one primary and one secondary, with average flow of $10.16 \mathrm{~L} \mathrm{~s}^{-1}$ of water. The uptake of the DSE was performed in the secondary facultative pond and pumped to a system of sand filters to remove solids. Table 2 presents the average values of the chemical quality of DSE used.

TABLE 2. Chemical characterization of the domestic sewage effluent used in irrigation (GOMES et al. 2009).

\begin{tabular}{rcccccccccc}
\hline \multirow{2}{*}{ Comp. } & ${\mathrm{N}-\mathrm{NH}_{4}{ }^{+}}$ & $\mathrm{NNO}_{3}^{-}$ & ${\mathrm{P}-\mathrm{PO}_{4}}^{-}$ & $\mathrm{K}^{+}$ & $\mathrm{Ca}^{2+}$ & $\mathrm{Mg}^{2+}$ & $\mathrm{Na}^{+}$ & $\mathrm{pH}$ & SAR & E.C. \\
\cline { 2 - 9 } Conc. & 26,33 & 0,07 & 2,53 & 23,73 & 14,15 & 4,97 & 66,90 & 7,47 & 3,82 & 0,82 \\
\hline
\end{tabular}

Comp. = Components; Conc. = Concentration; SAR - Sodium adsorption ratio; E.C. = Electrical Conductivity. 
The $\mathrm{N}_{-} \mathrm{NH}_{4}{ }^{+}$and $\mathrm{NNO}_{3}{ }^{-}$present in the DSE showed concentrations of 26.33 and $0.07 \mathrm{mg}$ $\mathrm{L}^{-1}$, values considered above and within, respectively, the limits allowed for use in irrigation (FAO, 1973). The concentration of $\mathrm{P}_{-} \mathrm{PO}_{4}{ }^{-}$, was $2.53 \mathrm{mg} \mathrm{L}-1$ and $\mathrm{K}^{+}$showed a value close to the effluent used for GALAVI et al. (2010), which was $22.62 \mathrm{mg} \mathrm{L}^{-1}$. The concentrations of $\mathrm{Ca}^{2+} \mathrm{and}_{\mathrm{Mg}^{2}}{ }^{+}$ recorded values of 14.15 and $4.97 \mathrm{mg} \mathrm{L}^{-1}$, lower than that observed for KALAVROUZIOTIS et al. (2008), when using DSE, with concentrations of 90.74 and $21.63 \mathrm{mg} \mathrm{L}^{-1}$, respectively. The $\mathrm{Na}^{+}$is the chemical element with the highest concentration, with a value of $66.90 \mathrm{mg} \mathrm{L}^{-1}$, the $\mathrm{pH}$ was close to neutrality, 7.47, and SAR, along with the electrical conductivity, were within the limit is allowed from 0 to $15 \mathrm{mmol} \mathrm{L}^{-1}$ and 0 and $3 \mathrm{dS} \mathrm{m}^{-1}$, respectively (FAO 1973).

Irrigation was carried out by a subsurface drip system, with side lines to $0.16 \mathrm{~m}$ depth. The emitters used were Netafim brand, model Super Typhoon spaced every $0.5 \mathrm{~m}$ with a flow rate of $1.75 \mathrm{~L} \mathrm{~h}^{-1}$ and wall thickness of $0.38 \mathrm{~cm}$.

Irrigation was performed three times a week (Monday, Wednesday and Friday) based on readings of evaporation occurred in a tank "class A", installed in the experimental area, which were then corrected by the crop coefficient $(\mathrm{Kc})$. For monitoring water content in the soil tensiometers were installed in the row, only the center of the plots of treatment T100\% next line of stumps, in layers of $0.00-0.20,0.20-0,40 ; 0.40-0.60 \mathrm{~m}$. Precipitation occurred during the experiment were recorded by a rain gauge installed in the experimental area, discounted on the blade and applied in the forty days that preceded the harvest was suspended irrigation to improve crop yields during ripening.

The rainfall data recorded during the four cycles of culture and historical series of Piracicaba SP, totaled 1,$463 ; 1,521 ; 1,088 ; 1,459$ and $1,230 \mathrm{~mm}$ for the plant cane (Sept/2006 the Aug/2007) $1^{\text {st }}$ ratoon ( the July/2008 Sept/2007) $2^{\text {nd }}$ ratoon (Jul/2008 the Set/2009) $3^{\text {rd }}$ ratoon (Set/2009 the $\mathrm{Jul} / 2010$ ) and the climatological normal region, respectively. Table 3 presents the irrigation with DSE applied in the culture of sugarcane in the 1st, 2nd and 3rd ratoon for all irrigated treatments. The sugarcane plant received no irrigation.

TABLE 3. Values of irrigation water depths in the $1^{\text {st }}, 2^{\text {nd }}$ and $3^{\text {rd }}$ sugarcane ratoons.

\begin{tabular}{cccc}
\hline \multirow{2}{*}{ Treatments } & \multicolumn{3}{c}{ DSE Depth $(\mathrm{mm})$} \\
\cline { 2 - 4 } & $1^{\text {st }}$ Ratoon & $2^{\text {nd }}$ Ratoon & $3^{\text {rd }}$ Ratoon \\
\hline T50\% & 348.30 & 302.63 & 205.86 \\
T100\% & 573.28 & 413.28 & 407.25 \\
T200\% & 1057.57 & 1054.72 & 818.23 \\
\hline
\end{tabular}

T50\% = Irrigation with in natura domestic sewage effluent (DSE) meeting 50\% of evapotranspiration (ETP); T100\% = Irrigation with in natura DSE meeting $100 \%$ of (ETP); T200\% = Irrigation with in natura DSE meeting $200 \%$ of (ETP).

The root system of sugarcane was evaluated based on the view of the trench through the interpretation of digital images, using the computer system SIARCS, version 3.0. Therefore, in each plot, in the transverse direction of the crop row and central irrigated, there was the opening of a trench with dimensions of $1.4 \mathrm{~m}$ wide, $1.2 \mathrm{~m}$ long and $1.0 \mathrm{~m}$ deep, taking as a reference center groove of the row, so that way the root system could be observed in layers spaced every $0.20 \mathrm{~m}$ and the maximum depth of the study, which was $0.8 \mathrm{~m}$ (Figure 1).

Then the profile of the trench was leveled with the aid of a shovel straight cut and scarified with a scarified roller spiral. This process was necessary to improve the exposure of the root system and encourage the painting of the roots, which was carried out with spray paint and white, or yellow. After this procedure, through the use of a backpack sprayer, the profile was washed with water and the roots maintained only painted (JORGE \& CRESTANA, 1996).

The collection of images of the root system was performed by a camera of the brand Sony with resolution set to 3 mega pixels. In all trenches machine was positioned at a depth of $0.40 \mathrm{~m}$ $1.20 \mathrm{~m}$ distanced from the wall profile thus received no treatment or been hampered by the position 
of the equipment. The photograph of each trench 20 has been divided into "sub-pictures," arranged in four rows and five columns, each representing the actual area of 0,056 $\mathrm{m} 2$ of the trench (Figure $1 \mathrm{~b}$ ).

a)

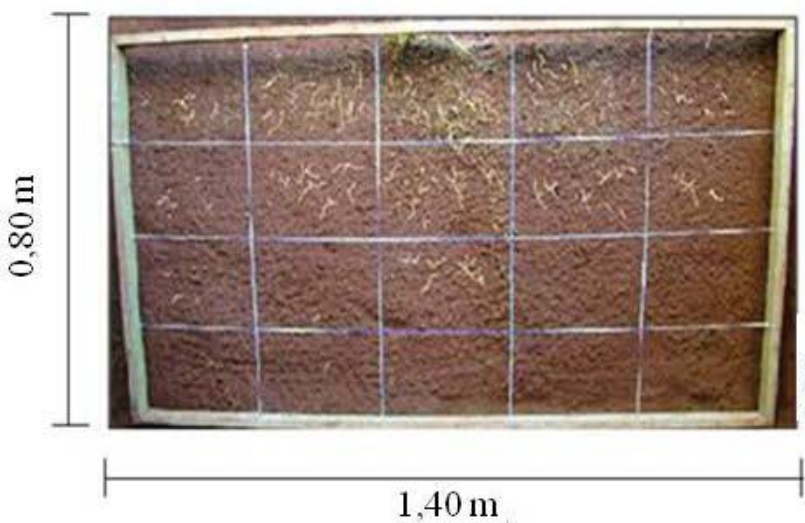

b)

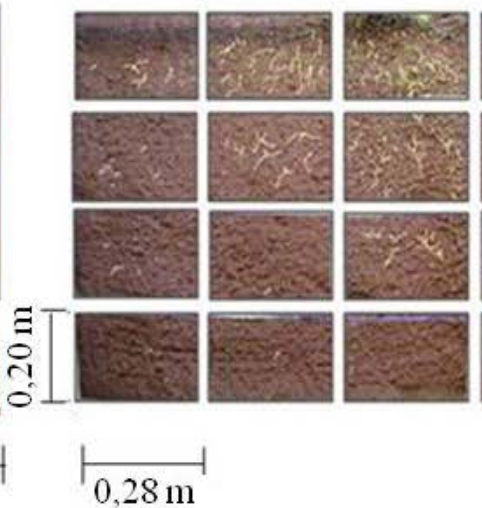

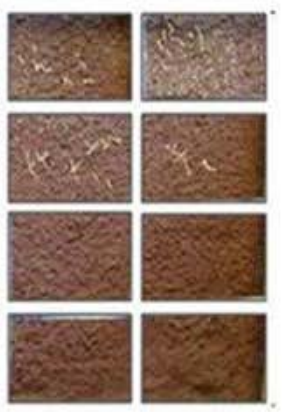

FIGURE 1.Cut picture (a), and sub-pictures that formed soil profile for analysis of root system (b).

After this step, the files had improved image quality in software 20/20 Version 2.2, converted to JPEG and saved in BPM format accepted by software SIARCS 3.0 (LIMA et al., 2006). Thus, it was possible to carry out studies on the root area, length and effective depth of the root system of the crop of sugarcane.

Data were submitted to analysis of variance and the means were compared by Tukey test at 5\% probability through computational system Sisvar version 5.1. The distribution maps of the root system in the soil profile were made using the computational system version 9.0 Surf.

\section{RESULTS AND DISCUSSION}

\section{Root Area}

The root system of plants subjected to treatment TWI presented the largest areas in all studied layers and layer only 0.60 to $0.80 \mathrm{~m}$ was equal to the average observed in the treatment $\mathrm{T} 50 \%$. Layers from 0.00 to 0.20 and from 0.20 to $0.40 \mathrm{~m}$ irrigated treatments did not differ statistically, although it had the lowest averages (Table 4).

TABLE 4. Sugarcane root area affected by the irrigation with domestic sewage effluent at different water depths of irrigation.

\begin{tabular}{cccccc}
\hline \multirow{2}{*}{$\begin{array}{c}\text { Soil layers } \\
(\mathrm{m})\end{array}$} & TWI & T50\% & T100\% & T200\% & CV\% \\
\cline { 2 - 5 } & & Root area $\left(\mathrm{cm}^{2}\right)$ & per grid of $0.056 \mathrm{~m}^{2}$ & \\
\hline $0.00-0.20$ & $21.91 \mathrm{a}$ & $9.97 \mathrm{~b}$ & $10.10 \mathrm{~b}$ & $13.52 \mathrm{~b}$ & 14.84 \\
$0.20-0.40$ & $12.26 \mathrm{a}$ & $4.40 \mathrm{~b}$ & $5.25 \mathrm{~b}$ & $6.61 \mathrm{~b}$ & 13.89 \\
$0.40-0.60$ & $3.50 \mathrm{a}$ & $4.65 \mathrm{a}$ & $2.07 \mathrm{a}$ & $3.01 \mathrm{a}$ & 33.82 \\
$0.60-0.80$ & $2.99 \mathrm{a}$ & $5.55 \mathrm{a}$ & $0.80 \mathrm{~b}$ & $0.97 \mathrm{~b}$ & 28.92 \\
\hline
\end{tabular}

Averages followed by the same letters in the line do not statistically differ by the Tukey's test $(\mathrm{P}<0.05)$. TWI = Rainfed crop; T50\% $=$ Irrigation with DSE meeting 50\% of ETP; T100\% = Irrigation with DSE meeting 100\% of ETP; T200\% = Irrigation with DSE meeting $200 \%$ of ETP.

In the layer from 0.60 to $0.80 \mathrm{~m}$, the values of root area in treatments T100 and T200\% were lower due to the fact of the irrigation system locate up to $0.16 \mathrm{~m}$ deep and are held three irrigations times a week, which meant that there was no water deficit. This procedure provided the first layers of soil and higher humidity did not stimulate deep root growth to deeper layers.

According VASCONCELOS \& GARCIA (2005) the drying of the soil, from the top down, makes the surface layers more resistant to root growth and stimulates root development in greater 
depth. This statement is reinforced by Farias et al. (2008), reporting that when irrigated plant sugarcane issues quickly root system, however, there is a deepening as pronounced as observed under rainfed conditions, because the roots tend to concentrate in the more humid soil.

In all treatments there was a higher concentration of root area in the layer 0.00 to $0.20 \mathrm{~m}$ more significantly in the region close to the axis of stumps. The TWI presented a root system expanded both laterally and in depth. In T50\%, despite the drought provided the culture was not observed an expansion of lateral root area so marked example of TWI, however, the effect of water deficit was evidenced by the deep root, since this treatment has roots as developed in depth, as observed in treatment that benefited from irrigation (Figure 2).

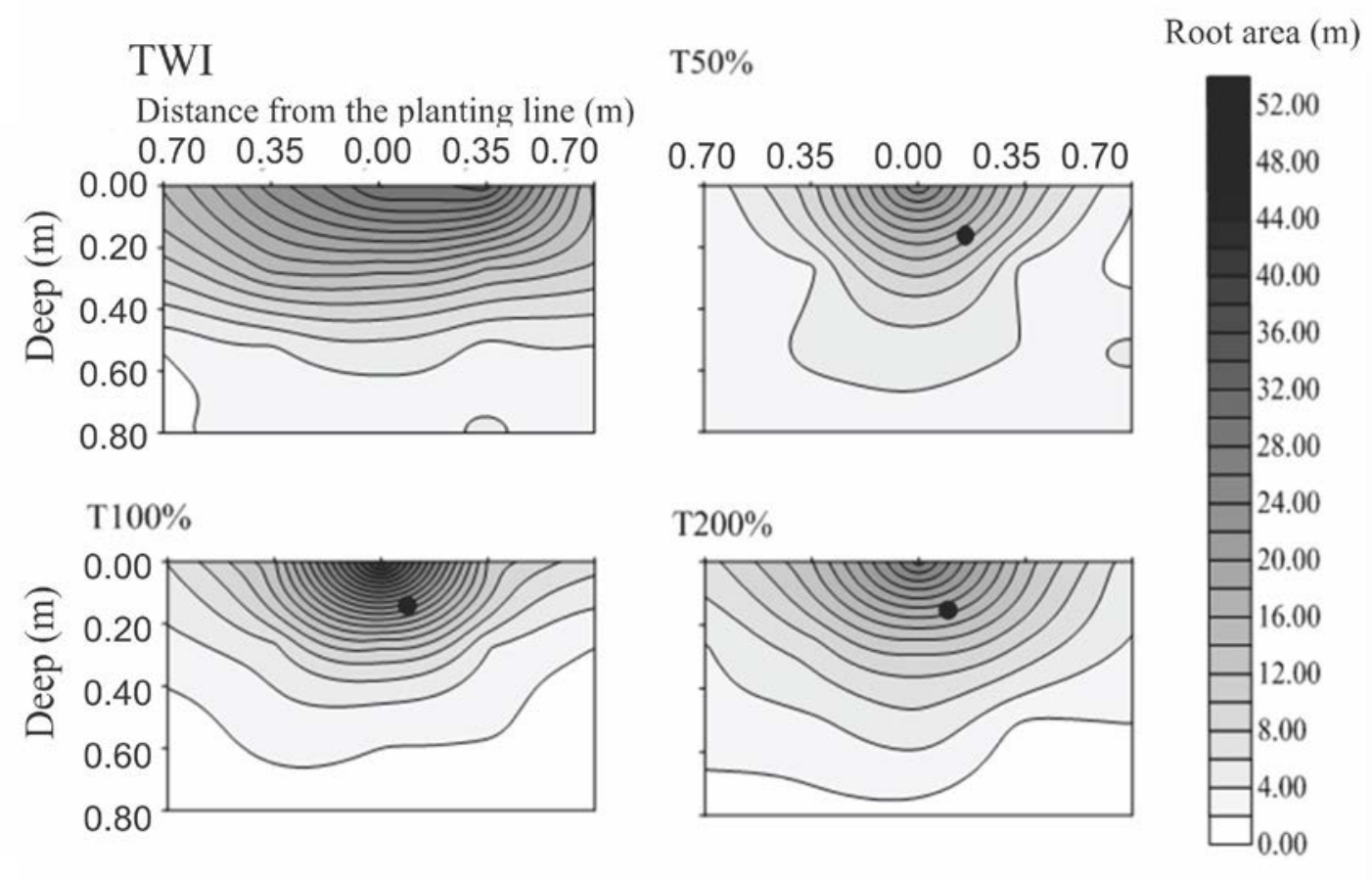

- Emitter tube buried at $0.16 \mathrm{~m}$ deep in the row

FIGURA 2. Distribution of the root area of sugar cane for the treatments: TWI=Treatment without irrigation; T50\%=Irrigation with DSE supplying 50\% of the ET; T100\%=Irrigation with DSE supplying $100 \%$ of the ET; T200\%=Irrigation with DSE supplying $200 \%$ of the ET.

Treatment T100\% had a smaller root expansion in depth when compared to treatments TWI and $\mathrm{T} 50 \%$, because the water requirement of plants subjected to this treatment was fully met (Figure 2).

The root system of plants subjected to the T200\% showed a lateral expansion and a depth greater than that seen in T100\%, however, noted the existence of roots with smaller areas in the region near the emitter tube. Although the T200\% has not offered water stress culture, the expansion of the root system may be justified by the fact that the application of the blade provide surplus forming a wetted with a larger area, along with the fact that the root growth occur preferably, in wet areas. With respect to smaller areas of roots observed in the region near the emitter, attributed to reduction of oxygen in the soil provided by the application of the blade surplus (Figure 2).

\section{Root length}

The TWI treatment showed the highest values of root length in all studied layers and layers only from 0.40 to 0.60 and 0.60 to $0.80 \mathrm{~m}$, showed an average equal to Treatment T50\% (Table 5). 
TABELA 5. Root length of sugarcane, for each pixel with $0,056 \mathrm{~m}^{2}$, affected by the irrigation with domestic sewage effluent with different water depths.

\begin{tabular}{cccccc}
\hline \multirow{2}{*}{$\begin{array}{c}\text { Soil layers } \\
(\mathrm{m})\end{array}$} & TWI & T50\% & T100\% & T200\% & CV\% \\
\cline { 2 - 6 } & \multicolumn{5}{c}{ Root length $(\mathrm{cm})$} \\
\hline $0.00-0.20$ & $179.60 \mathrm{a}$ & $124.67 \mathrm{~b}$ & $135.32 \mathrm{~b}$ & $123.45 \mathrm{~b}$ & 3.76 \\
$0.20-0.40$ & $94.17 \mathrm{a}$ & $49.73 \mathrm{~b}$ & $45.94 \mathrm{~b}$ & $60.61 \mathrm{~b}$ & 8.69 \\
$0.40-0.60$ & $32.45 \mathrm{a}$ & $33.55 \mathrm{a}$ & $21.26 \mathrm{~b}$ & $22.61 \mathrm{~b}$ & 8.95 \\
$0.60-0.80$ & $27.64 \mathrm{a}$ & $20.21 \mathrm{a}$ & $7.14 \mathrm{~b}$ & $5.45 \mathrm{~b}$ & 29.34 \\
\hline
\end{tabular}

Averages followed by the same letters in the line do not statistically differ by the Tukey's test $(\mathrm{P}<0.05)$. TWI = Rainfed crop; T50\% $=$ Irrigation with DSE meeting 50\% of ETP; T100\% = Irrigation with DSE meeting 100\% of ETP; T200\% = Irrigation with DSE meeting $200 \%$ of ETP.

The example of the behavior of the root area, root length was also reduced by the use of irrigation with DSE. This can be confirmed by observing the highest average length treatments TWI and T50\% at depths 0.40 to 0.60 and from 0.60 to $0.80 \mathrm{~m}$, and these treatments the only conditions in which the water requirement of the crop not was met by irrigation (Table 5).

SOUSA (2012) to study the influence of DSE on soil chemical properties in the same area and the same year in which this research was conducted, verified the irrigated treatments higher levels of nutrients such as $\mathrm{N}, \mathrm{K}, \mathrm{Ca}$ and with values of $\mathrm{Mg}, 21.40 \%, 3.61 \%, 38.34 \%$ and $100 \%$, respectively, higher than the TWI. This fact may have contributed to that there was the need of the plants subjected to irrigation, deepen the root system for nutrients, corroborating OTTO et al. (2009), to establish that deep root growth also occurs when the plant needs to absorb nutrients essential to their development.

There was a decrease in root length values in the profiles of all treatments increased as the depth of the soil layer. However, the distribution of root length observed in the treatment TWI levels were more homogeneous in the soil profile compared to irrigated treatments, which showed greater root length in the region near the emitter tube (Figure 3).

\section{TWI}
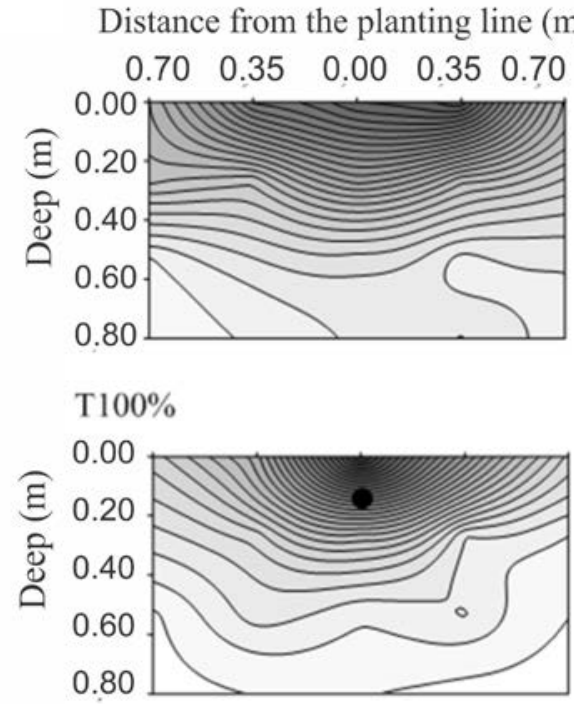

$\mathrm{T} 50 \%$

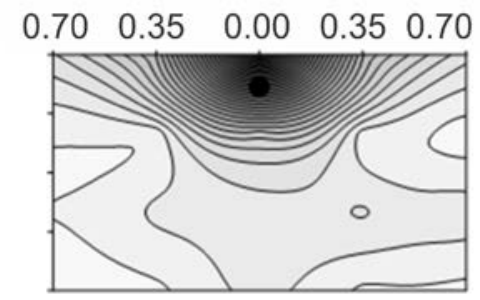

T200\%

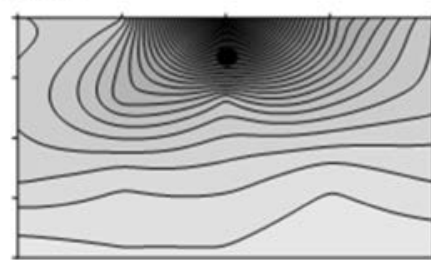

Root area $\left(\mathrm{cm}^{2}\right)$

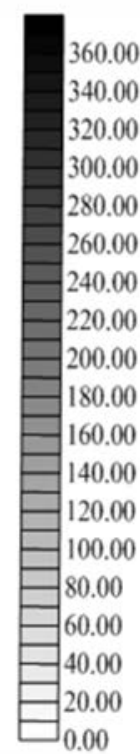

- Emitter tube buried at $0.16 \mathrm{~m}$ deep in the row

FIGURA 3. Distribution of the root length of sugar cane for the treatments: TWI=Treatment without irrigation; T50\%=Irrigation with DSE supplying $50 \%$ of the ET; T100\%=Irrigation with DSE supplying $100 \%$ of the ET; T200\%=Irrigation with DSE supplying $200 \%$ of the ET. 
BUSO et al. (2009) also observed a decrease in root length as to increase the depth in the soil profile. SANTOS (2010) states that subsurface drip irrigation provides a more homogeneous distribution of roots in the profile, different cultivation without irrigation where there is a predominance of roots in the first layer.

\section{Effective Root Depth}

Based on the cumulative distribution of root length was possible to determine the effective depth of the root system of sugarcane, which is defined by BERNARDO et al. (2005), as the depth from the surface, where they are accumulated $80 \%$ of the root system.

Treatments IST, T100 and T200\% had effective depths in the first $0.40 \mathrm{~m}$ from the soil surface, and not statistically different. On that same layer, T50\% treatment had the lowest mean observed, concentrating $76.43 \%$ of total roots (Figure 4).

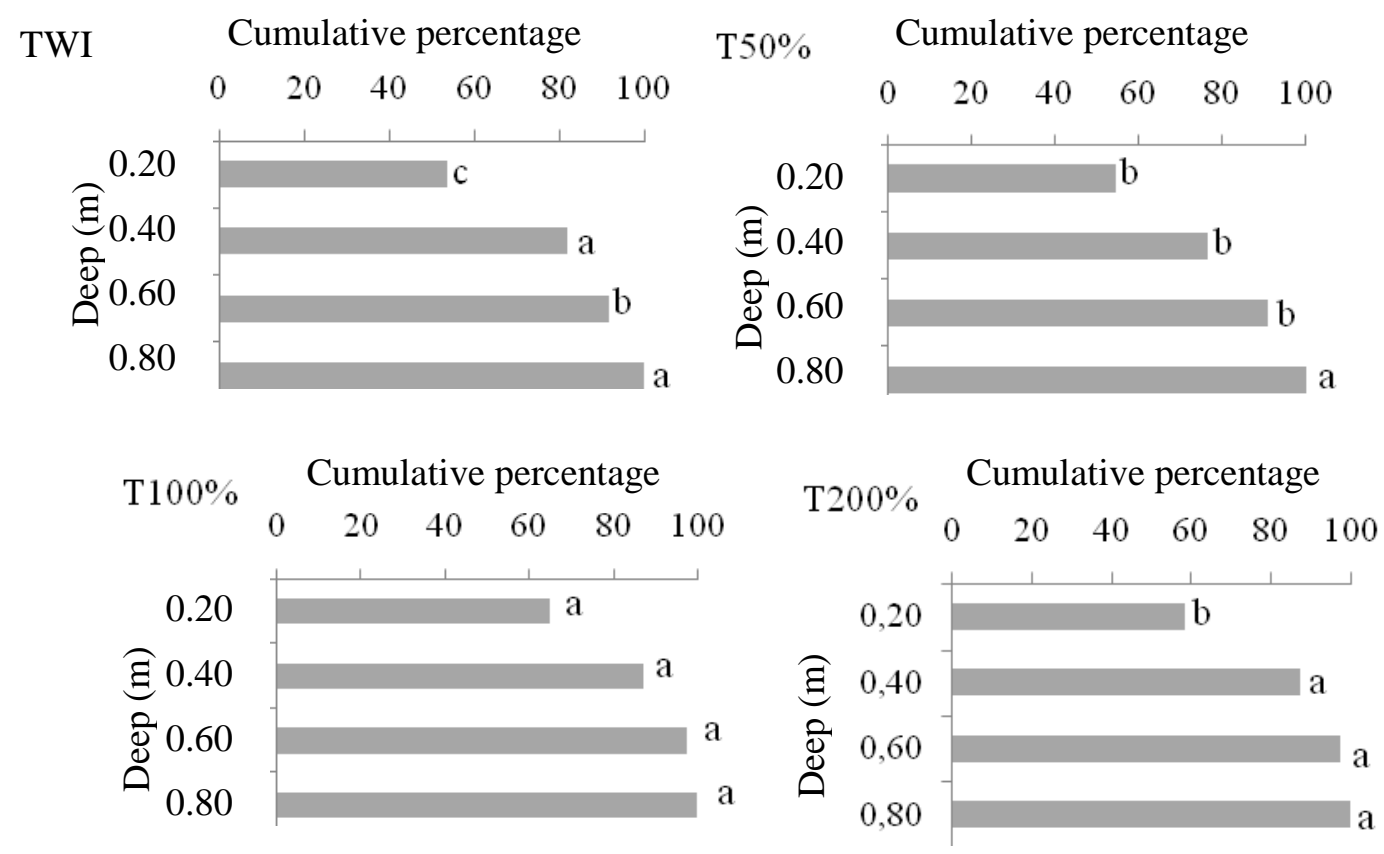

FIGURA 4. Cumulative percentage of the root length of sugar cane for the treatments: TWI = Treatment without irrigation; T50\% = Irrigation with DSE supplying 50\% of the ET; T100\% = Irrigation with DSE supplying 100\% of the ET; T200\% = Irrigation with DSE supplying $200 \%$ of the ET. Means followed by the same letter at the same depth are not statistically different by Tukey test $(\mathrm{P}<0.05)$.

The deep root growth observed in T50\% associated with less lateral expansion in the layer from 0.00 to 0.20 (Figure 3) may have been responsible for not checking the $80 \%$ of the root system in the first $0.40 \mathrm{~m}$.

The absence of irrigation with treatment TWI stimulated deep root growth and further development side, especially in the layer from 0.00 to $0.20 \mathrm{~m}$, which ensured the concentration of $80 \%$ of the roots depth of $0.00-0.40 \mathrm{~m}$. Results of cumulative percentage of roots occurred in all treatments are according to Farias et al. (2008), in stating that in general, up to $76 \%$ of the roots of sugarcane are the first $0.45 \mathrm{~m}$ of soil depth. These authors evaluated the development of the root system of sugar cane irrigated and cultivated without irrigation after 280 days of implantation of the experiment, and observed that the sugar cane grown without irrigation in $80 \%$ of the dry weight of roots in the first $0,60 \mathrm{~m}$ depth of soil, and when irrigated, that figure increased to $90 \%$.

In assessing the development of the root system of raw and burnt sugarcane ALVAREZ et al. (2000) reported that $75 \%$ of the root system found itself in the first $0.40 \mathrm{~m}$ of the soil and burnt sugarcane, reduced to $72 \%$, this actually refers to the highest values of soil moisture provided by 
permanence of the straw when the sugarcane is harvested green. To Inforzato \& ALVAREZ (1957), 59\% of the roots are in $0.30 \mathrm{~m}$ surface. BALL-COELHO et al. (1992) found that $62.70 \%$ of the numbers of roots are located at a depth of 0.00 to $0.50 \mathrm{~m}$.

\section{CONCLUSIONS}

1. Irrigation with wastewater effluent reduced the area and length of the root system of sugarcane.

2. Treatments TWI and T50\% stimulated root development in deeper layers.

3. Irrigation with wastewater effluent concentrated root system in the region close to the dripline and reduced the depth of the roots.

4. TWI treatments, T100 and T200\% the effective depth of the root system reached the layer from 0.00 to $0.40 \% \mathrm{~m}$ in $\mathrm{T} 50$ layer from 0.00 to $0.60 \mathrm{~m}$.

5. Based on the development of roots, may be applied to domestic sewage effluent for irrigation of the sugarcane.

\section{REFERENCES}

ALVAREZ, I. A. CASTRO, P. R. C.; NOGUEIRA, M.C. S. Crescimento de raízes de cana crua e queimada em dois ciclos. Revista Scientia Agrícola, Piracicaba, v. 57, n. 4, p. 653-9, out./dez. 2000.

BALL-COELHO, B.; SAMPAIO, E. V. S. B.; TIESSEN, H.; STEWART, J. W. B. Root dynamic in plant ratoon crops of sugar cane. Plant and soil, The Hague, v. 142, p. 297-305, 1992.

BARROS, A. C.; FOLEGATTI, M., V.; SOUZA, C. F.; SANTORO, B. Distribuição da solução no solo por gotejo enterrado e superficial. Revista Irriga, Botucatu, v. 15, n. 4, p. 361-372, out/dez. 2010.

BARROS, A. C.; FOLEGATTI, MARCOS, V.; SOUZA, C. F.; SANTORO, B. Distribuição de água no solo aplicado por gotejamento enterrado e superficial. Revista Brasileira de Engenharia Agrícola e Ambiental, Campina Grande, v.13, n. 6, p.700-7, dez. 2009.

BERNARDO, S.; SOARES, A. A.; MONTOVANI, E. C. Manual de irrigação. 7. ed. Viçosa: Ed. UFV, 2005.

BUSO, P. H. M.; KOEHLER, H. S.; DAROS, E.; ZAMBON, J. L. C.; IDO, O. T.; BESPALHOKFILHO, J. C.; WEBER, H. OLIVEIRA, R. A.; ZENI NETO, H. Sistema radicular da variedade RB85535 de cana-de-açúcar no plantio em minitolete e tolete, Revista Scientia Agrária, Curitiba, v.10, n.5, p. 343-349, set./out. 2009.

COELHO, E. F.; SANTOS, D. B.; AZEVEDO, C. A. V. Sensor placement foi soil monitoring in lemon irrigated by micro sprinkler. Revista Brasileira de Engenharia Agrícola e Ambiental, Campina Grande, v.11, n. 1, p. 46-52, fev. 2007.

COELHO, E. F.; SANTOS, M. R.; COELHO FILHO, M. A. Distribuição de raízes de mamoeiro sob diferentes sistemas de irrigação localizada em latossolo de tabuleiros costeiros. Revista Brasileira de Fruticultura, Jaboticabal, v.27, n.1, p. 175-178, abr. 2005.

COELHO, E. F. SILVA.; SILVA, A. J. P.; MIRANDA, J. H. Definição do posicionamento de sensores para monitoramento da água no solo em bananeira irrigada por diferentes sistemas de irrigação localizada. Engenharia Agrícola, Jaboticabal, v.30, n.4, p. 608-618, jul./ago. 2010.

COSTA, M. C.; MAZZA, J. A.; VITTI, C. G.; JORGE, L. A. C. Distribuição radicular, estado nutricional e produção de colmos e de açúcar em soqueiras de dois cultivares de cana-de-açúcar em solos distintos. Revista Brasileira de Ciência do Solo, Viçosa-MG, v.31, p. 1503-1514, dez. 2007. 
DEON, M. D. Reciclagem de águas e nutrientes pela irrigação da cana-de-açúcar com efluente de tratamento de esgoto. 2010. 89 f. Tese (Doutorado em Ciências) - Escola Superior de Agricultura “Luiz de Queiroz”, Universidade de São Paulo, Piracicaba, 2010.

DEON, M. D.; GOMES, T. M.; MELFI, A. J.; MONTES, C. R.; SILVA, E. Produtividade e qualidade da cana-de-açúcar irrigada com efluente de esgoto de estação de tratamento de esgoto. Pesquisa Agropecuária Brasileira, Brasília, v.45, n.10, p.1149-1156, out. 2010.

FAO UNESCO. Food and Agriculture Organization of the United Nations. Irrigation, drainage and salinity: an international source book. London: Hutchinson/FAO/UNESCO, 1973. 510p.

FARIAS, C. H. A.; FERNANDES, P. D.; AZEVDO, H. M.; DANTAS NETO, J. Índice de crescimento de cana-de-açúcar irrigada e de sequeiro no estado da Paraíba. Revista Brasileira de Engenharia Agrícola e Ambiental, Campina Grande, v. 12, n.4, p. 356-362, ago. 2008.

FONSECA, A. F.; HERPIN, U.; PAULA, A. M. VICTÓRIA, R. L.; MELFI, A. J. Agricultural use of treated sewage effluents: Agronomic and environmental implications and perspectives for Brazil. Scientia Agrícola, Piracicaba, v. 64, n.2, p.194-209. Mar./abr. 2007.

GALAVI, M.; JALALI, A.; RAMROODI, M.; MOUSAVI, S, R.; GALAVI, H. Effects of treated municipal wastewater on soil chemical properties and heavy metal uptake by sorghum (Sorghum bicolor L.). Journal of Agricultural Science, Amsterdam, v. 2, n. 3, p. 235 - 241, 2010.

GOMES, T. M.; MELFI, A. J.; MONTES, C. R. SILVA, E.; SUNDEFELD JUNIOR, G. C.; DEON, M. D.; PIVELI, R. P. Aporte de nutrientes e estado nutricional da cana-de-açúcar irrigada com efluente de estação de tratamento de esgoto com e sem desinfecção. Revista DAE, São Paulo, v. 180, p. 17 - 23, 2009.

INFORZATO, R.; ALVAREZ, R. Distribuição do sistema radicular da cana-de-açúcar var. Co. 290, em solo tipo Terra-Roxa-Legítima. Bragantia, Campinas. v.16, n.1, p.1-13, out. 1957.

JORGE, L. A. C. CRESTANA, S. Recomendações práticas para utilização do SIARCS 3.0 no estudo de raízes, cobertura vegetal, folhas e outras aplicações. n. 4. São Carlos: Embrapa Instrumentação Agropecuária, 1996. 23 p. (Boletim Técnico).

KALAVROUZIOTIS, I. K.; ROBOLAS, P.; KOUKOULAKIS, P. H.; PAPADOPOULOS, A. H.; Effects of municipal reclaimed wastewater on the macro-and micro elements status of soil and of Bassica oleracea var. Italica, and B. oleracea var. Germmifera. Amsterdam Agricultural Water Management, Amsterdam, v. 95, p. 419 - 426, 2008.

KALAVROUZIOTIS, K. I.; KOUKOULAKIS, P. H.; SAKELLARIOU-MAKRANTONAKI, M.; PAPANIKOLAOU, C. Effects of treated municipal wastewater o the essential nutrients interactions in the plant of Brassica oleracea var. Itálica. Desalination, Amsterdam, v. 242, p. 297-312, 2009.

LIMA, W. L. OLIVEIRA, J. R. SAGGIN JUNIOR, O. J. RAPOSO, T. P. ALVES, G. C. SILVA, E. M R. BERBARA, R. L. L. Editoração de imagens para avaliação de crescimento de plantas ou microrganismos com programa SIARCS. Seropedica: Embrapa Agroecologia Rio de Janeiro, 2006. 32p. (Boletim Técnico).

NEVES, C. S. V. J.; STENZEL, N. M. C.; CARVALHO, S. L. C.; FURLANETO, T. L. R.; OKUMOTO, S. H. Sistema radicular de quatro porta-enxerto sob copa de tangerina pocã. Revista Ciência e Agrotecnologia, Lavras, v. 32, n.2, p. 487-492, mar./abr. 2008.

OTTO, R.; FANCO, H. C. J.; FARONI, C. E.; VITTI, A. C.; TRIVELIN, P. C. O. Fitomassa de raízes relacionada à adubação nitrogenada de plantio. Revista de Pesquisa Agropecuária, Brasília, v. 44, n. 4, p. 398 - 405, abr. 2009. 
RAIJ, B. VAN.; CANTARELLA, H.; QUAGGIO, J. A.; A. M.C. FURLANI, A. M. C (Ed). Recomendações de adubação e calagem para o estado de São Paulo. 2 ed. Campinas: Instituto Agronômico, 1996. 285p . (Boletim Técnico, 100).

RAMOS, A.; FOLEGATTI, M. V.; BOVI, M. L. A.; DIOTTO, A. V. Distribuição espacial do sistema radicular da pupunheira em função das lâminas de irrigação. Revista Irriga, Botucatu, v.14, n. 4, p. 431-440, out/dez. 2009.

RIBEIRO, A. A.; COELHO, R. D.; TEIXEIRA, M. B. Entupimento de tubos gotejadores convencionais com aplicação de cloreto de potássio (branco e vermelho) via duas qualidades de água. Engenharia Agrícola, Jaboticabal, v. 30, n. 2, p. 279-287, mar./abr. 2010.

SANDRI, D.; MATSURA, E. E. M.; TESTEZLAF, R. Alteração química do solo irrigado por aspersão e gotejamento subterrâneo e superficial com água residuária. Revista Brasileira de Engenharia Agrícola e Ambiental, Campina Grande, v.13, n.6, p.755-764, dez. 2009.

SANTOS, J. S.; LIMA, V. L. A.; BORGES JUNIOR, J. C. F.; SILVA, L. V. B. D.; AZEVEDO, C. A. V. Mobilidade de solutos em coluna de solo com água residuária doméstica e de suinocultura. Revista Brasileira de Engenharia Agrícola e Ambiental, Campina Grande, v.14, n.11, p.1226-1233, nov. 2010.

SANTOS, D. Distribuição do sistema radicular e produtividade de cana-de-açúcar (saccharum ssp) fertirrigada por gotejamento subsuperficial. 2010. 85 f. Dissertação (Mestrado em Agronomia) - Universidade Estadual Paulista, Faculdade de Ciências Agronômicas, Botucatu, 2010.

SOUSA, A. C. M. Uso da irrigação subsuperficial com efluente de esgoto doméstico em área cultivada com Cana-de-açúcar. 2012. 123 f. Dissertação (Mestrado em Engenharia Agrícola) Universidade Estadual de Campinas, Campinas, 2012.

VASCONCELOS, A. C. M.; GARCIA, J. C. Desenvolvimento radicular da cana-de-açúcar. Piracicaba: Potafos. 2005. 32p. Encarte Técnico. 


\section{ERRATA: volume 33, número 4}

p.653, na figura 3, onde se lê:

Root area (m).

Leia-se:

Leia-se:

Root area $\left(\mathrm{cm}^{2}\right)$

p.651, onde se lê:

"In the layer from 0.60 to $0.80 \mathrm{~m}$, the values of root area in treatments T100 and T200\%\% were lower due to the fact of the irrigation system locate up to $0.16 \mathrm{~m}$ deep and are held three irrigations times a week, which meant that there was no water deficit. This procedure provided the first layers of soil and higher humidity did not stimulate deep root growth to deeper layers!"

\section{Leia-se:}

"In the layer from 0.60 to $0.80 \mathrm{~m}$, the values of root area in treatments T100 and T200\% were lower due to the fact of the irrigation system locate up to $0.16 \mathrm{~m}$ deep and are held three irrigations times a week, which meant that there was no water deficit. This procedure provided the first layers of soil and higher humidity did not stimulate deep root growth to deeper layers." 